May 2020

\title{
Indicators of Impactful Reflection in Pre-Service Teachers: A Case for Creativity, Honesty and Unfamiliar Experiences
}

Sarah Marie Catalana

Winthrop University, catalanas@winthrop.edu

Follow this and additional works at: https://digitalcommons.georgiasouthern.edu/ij-sotl

\section{Recommended Citation}

Catalana, Sarah Marie (2020) "Indicators of Impactful Reflection in Pre-Service Teachers: A Case for Creativity, Honesty and Unfamiliar Experiences," International Journal for the Scholarship of Teaching and Learning: Vol. 14: No. 1, Article 14.

Available at: https://doi.org/10.20429/ijsotl.2020.140114 


\title{
Indicators of Impactful Reflection in Pre-Service Teachers: A Case for Creativity, Honesty and Unfamiliar Experiences
}

\begin{abstract}
This study investigated three commonalities among pre-service teachers who demonstrated advanced reflective practice regarding fieldwork experiences: (a) creative potential; (b) honesty in confronting misconceptions of the teaching profession, and (c) fieldwork in unfamiliar settings. Forty-two pre-service teachers submitted reflective papers which were qualitatively analyzed and scored for reflective ability using Harland and Wondras's (2011) Framework of Four Levels of Reflection for Teacher Education. Low and High Reflectors were compared in terms of creative potential, as measured by the Torrance Tests of Creative Thinking-Figural. Results revealed Low Reflectors generally demonstrated lower creative potential than High Reflectors, with a significant difference $(p<.05)$ in mean scores on the Abstractness of Titles subscale. High Reflectors also bluntly confronted previous misconceptions concerning education and described their field placements as unfamiliar when compared to their personal educational experiences. Implications for support of meaningful reflective practice in future educators are discussed in detail.
\end{abstract}

\section{Keywords}

reflection, creativity, pre-service teacher education, field experiences

\section{Creative Commons License}

(c) (i) $\ominus$

This work is licensed under a Creative Commons Attribution-Noncommercial-No Derivative Works 4.0 License. 


\title{
Indicators of Impactful Reflection in Pre-Service Teachers: A Case for Creativity, Honesty and Unfamiliar Experiences
}

\author{
Sarah Marie Catalana \\ Winthrop University \\ Received: 5 June 2019;Accepted: I5 November 2019
}

\begin{abstract}
This study investigated three commonalities among pre-service teachers who demonstrated advanced reflective practice regarding fieldwork experiences: (a) creative potential; (b) honesty in confronting misconceptions of the teaching profession, and (c) fieldwork in unfamiliar settings. Forty-two pre-service teachers submitted reflective papers which were qualitatively analyzed and scored for reflective ability using Harland and Wondras's (20I I) Framework of Four Levels of Reflection for Teacher Education. Low and High Reflectors were compared in terms of creative potential, as measured by the Torrance Tests of Creative Thinking-Figural. Results revealed Low Reflectors generally demonstrated lower creative potential than High Reflectors, with a significant difference ( $P$ $<.05$ ) in mean scores on the Abstractness of Titles subscale. High Reflectors also bluntly confronted previous misconceptions concerning education and described their field placements as unfamiliar when compared to their personal educational experiences. Implications for support of meaningful reflective practice in future educators are discussed in detail.
\end{abstract}

\section{INTRODUCTION}

The teaching profession is characterized by constant surprises. Each day brings new student dynamics, additional academic content to cover, unique social challenges, and unending realworld issues to resolve. No amount of teacher education courses can fully prepare a first-year teacher for the moment when she walks into the classroom and realizes her teaching experiences are not commensurate with those described in educational textbooks. This clash between expectation and reality must be met with flexibility and innovation; effective educators reflect upon their experiences and consider creative solutions to classroom challenges that progress beyond temptations to simply teach the way they were taught (Badiali \& Hammond, 2002; Cochran-Smith \& Lytle, 1999; Lortie, 1975).

Teacher education programs (TEPs) strive to cultivate the professional dispositions that equip future educators to adapt to diverse teaching challenges (Badiali, Nolan, Zembal-Saul, \& Manno, $20 \mathrm{II}$ ). Successful adaptation requires educators to adopt an inquiry stance towards teaching, which is characterized by active problem-solving, rather than the passive application of prescribed teaching methods (Badiali \& Hammond, 2002; Cochran-Smith \& Lytle, 1999). This inquiry stance is rooted in both reflective and creative thinking; educators reflect on their circumstances to recognize opportunities for growth and use creative thinking skills to consider diverse explanations for experiences and innovative responses to challenges.

Teacher educator programs often lay the foundation for the development of the inquiry stance as they encourage students to critically reflect on various experiences in the field (Clarke, Triggs \& Nielsen, 2014; Darling-Hammond, 2000; Gareis \& Grant, 20I4). Field experiences expose future teachers to a variety of educational settings, providing a real-world environment in which students grapple with the clash between the expectations and realities of the teaching profession. However, although the assertion to cultivate reflective educators is clear, research has revealed little evidence of advanced reflective skills on the part of future teachers, many of whom attempt to apply educational theory to practice without considering the unique characteristics of diverse teaching and learning environments (Farr \& Riordan, 20I5; Hatton \& Smith, 1995; King, 1997; Sellars, 2014; Yang, 2009).

This study emerged from a frustration which, unfortunately, plagues many teacher-educators: the clear gap between educational theory and practice. After reading countless reflection papers that were inundated with trite and cliché statements, I was determined to critically examine commonalities among advanced reflectors. What are the indicators of impactful reflective practice? And, more importantly, how can these commonalities inform the creation of successful teacher education programs? Such an in-depth analysis of reflection moves beyond the cliché, informing teacher educators how to successfully cultivate reflective practice and equip students to implement change in their future classrooms.

\section{REVIEW OF THE LITERATURE Reflective Practice}

Teacher education programs aim to cultivate teachers who are knowledgeable in both academic and pedagogical content, but PSTs are likely to resist educational theory that conflicts with their personal learning experiences (Furlong, 2013; Garmon, 2005; Rosaen, 2003). One method often used to counter such resistance is the encouragement of reflective thinking (Killeavy \& Moloney, 2010; Rodgers, 2002). Theoretically, reflection serves as a vehicle for change in education; PSTs remain open-minded to consider multiple explanations of their experiences, investigating underlying assumptions and consulting various sources for additional information. However, although teacher education programs enthusiastically embrace reflective practice, definitions of reflection and methods to enhance reflective practice are quite vague (Rodgers, 2002, Choy \& Oo, 2012). As Rodgers (2002) claimed, "in becoming everything to everybody, it [reflection] has lost its ability to be seen" (p. 843). 
The literature on reflection finds its roots in the work of John Dewey, who claimed that reflection blossoms from realworld problems that disquiet the thinker and motivate her to resolve the issue by persistent and reasoned thinking (Dewey, 1910; 1933; Sellars, 2014). Thus, reflection is a "meaning-making process" that "requires attitudes that value the personal and intellectual growth of oneself and of others" (Rodgers, 2002, p. 845) Schon's (1983) work, The Reflective Practitioner, further developed Dewey's foundational ideas and proposed two types of reflection: reflection-on-action and reflection-in-action. Reflection-on-action is retroactive in nature, but the notion of reflection-in-action "requires practitioners to construct new understanding towards a unique situation that will guide action while the situation is unfolding" (Lu, 20I3, p. I4). Thus, a "modified action", rather than a simple re-telling of experiences, is the ultimate goal of reflective practice (Hatton \& Smith, 1995, p. 34).

Although definitions of reflection vary in their nuances, a common theme across definitions is the existence of an "advanced" or "sophisticated" level of reflective thought that is characterized by modified action resulting from the unearthing of an assumption or misunderstanding (e.g., Harland \& Wondra, $201 \mathrm{I}$; Jay \& Johnson, 2002; Kember et al., 2008; Mezirow, I98I; 1991; 1992; Valli, 1990; Van Manen, 1977). Many researchers have labeled this type of reflection as "critical reflection", emphasizing its social impact and transformative nature. For example, Harland and Wondra (20II) proposed that reflective writing be sorted into four levels: Non-Reflection, Understanding, Reflection, and Critical Reflection. The lower levels of Non-Reflection and Understanding are mainly reactive in nature, but Reflection and Critical Reflection are characterized by an intentional analysis of past experiences to inform future action.

Unfortunately, research has demonstrated a steady lack of critical reflection on the part of future educators (Farr and Riordan, 20 15; Hatton \& Smith, 1995; King, 1997; Sellars, 2014; Yang, 2009), many of whom have not "reflected critically upon the ideological qualities of their knowledge and their own misunderstandings... and have no concrete understanding of or commitment to teaching for change" (King, 1977, p. 157). The majority of future educators have demonstrated reflective thinking that is characteristic of lower levels on reflection frameworks, such as Harland and Wondra's (20II) Nonreflection and Understanding categories. Such reflections often over-emphasize descriptions of their experiences and neglect to critically analyze how experiences can inform future action (Harland \& Wondra, 20I I; Yang, 2009).

Pre-service teachers gradually evolve from students to professionals as they participate in various field experiences and courses throughout their teacher preparation programs. Thus, PSTs form new and sophisticated understandings of teaching and learning as they reflect and juxtapose their personal educational experiences with the content and experiences offered throughout teacher preparation programs.

\section{The Apprenticeship of Observation and the Importance of Unfamiliar Experiences}

Teaching is a unique profession in that virtually all students who are studying to become educators (often referred to as pre-service teachers or PSTs) have spent thousands of hours observing and evaluating professionals in the field. In contrast to individuals who wish to become lawyers or doctors, for example, many PSTs enter formal training with what they believe to be a sophis- ticated understanding of what is necessary for success in their chosen profession. Lortie (1975) described this phenomenon as the apprenticeship of observation, claiming that PSTs enter TEPs with preconceived notions about teaching and learning that were formed throughout their experiences as students. If left unexamined, these preconceived notions often lead to intuitive and imitative forms of teaching, resulting in "ready-made recipes for action and interpretation that do not require testing or analysis while promising familiar, safe results" (Buchmann, 1987, p. I6I).

Given the juxtaposition between PSTs who are predominantly white and female (Bitterman, Goldring, \& Gray 20I3) and student populations which have recently reached a "majority minority" (Maxwell, 20I4), it is particularly important that PSTs resist temptations to teach the way they were taught and creatively adapt practices to appropriately serve all students (Badiali \& Hammond, 2002; Badiali, Nolan, Zembal-Saul, \& Manno, 20 I I; Borg, 2004; Gay, 2000). Indeed, the transformation from student to teacher begins with an "examination of one's own cultural assumptions and/or biases, which stem from our education, experiences with diverse groups, and our own student experience as part of a minority or majority population" (Markos, 2012 p. 43).

Although future educators have spent a significant amount of time observing teachers throughout the apprenticeship of observation, they are likely to form misconceptions about teaching and learning during this time since they only see the classroom from the limited vantage point of the student (Borg, 2004; Lortie, 1975). One of the central aims of teacher preparation is to confront such misconceptions and challenge PSTs to filter personal interpretations through research-based theory (Furlong, 20I3). As Lortie (1975) proposed,"the mind of the education student is not a blank awaiting inscription" (p. 66).

The sophistication of reflective practice is deeply intertwined with the experiences the individual is critically examining (Boud and Walker, 1998; Lee, 2005). Analysis of assumptions often stems from experiences that jerk individuals out of their comfort zones and starkly contradict expectations. These "critical incidents" or "disorienting dilemmas" lead individuals to check their assumptions and seek explanations through consulting multiple viewpoints (James \& Brookfield, 20 I4; Mezirow, 1998). Thus, PSTs working in unfamiliar or challenging environments are likely to demonstrate advanced reflective thinking skills because such experiences fuel reflection and trigger individuals to search for something that is missing from their existing worldview (James \& Brookfield, 2014; Mezirow, 1998; Taylor, 1998).

\section{Intersection Between Reflection and Creativity}

The literature on reflection often indirectly references creativity, revealing similarities between the two processes and demonstrating how creative thinking can enhance reflective practice (Brookfield 1988; Gibbs, 1988; James \& Brookfield, 2014; Killeavy \& Moloney, 2010; Lucas, 1991; Hatton \& Smith, 1995). Although definitions of creativity are as diverse as those of reflection, the "standard definition" (Runco \& Jeager, 20I2), asserts that creative ideas must be both original (new and unfamiliar) and appropriate (fulfilling a purpose). The out of the box thinking which characterizes creativity requires an open-minded examination of deeply held beliefs, thus priming the confrontation of potential misunderstandings that is central to advanced reflective practice (Nielsen, 20I4). 
Since creativity is a multifaceted construct, it is often discussed through Rhodes's (196I) framework of the Four P's of Creativity: (a) Person: Which characteristics are common among creative individuals; (b) Process: What are the steps leading to creative production; (c) Press:What makes an environment conducive to creative thought; and (d) Product: What qualifies as a creative product. Examining the literature on reflection through these Four P's reveals several similarities between the two constructs.

Person. Openness to experience and tolerance of ambiguity, both characteristics of creative individuals (see Barron, 1969; Charyton \& Snelbecerk, 2007; John, Naumann, \& Soto, 2008), build the foundation for meaningful reflection that is marked by a willingness to question one's beliefs and interpret experiences from multiple viewpoints (Goleman, 1985; Van Manen, 1977). Such a tolerance of ambiguity is associated with a willingness to take creative risks (Piirto, 2005), which, in the context of critical reflection often manifests as a risky, yet beneficial analysis of one's narrow and potentially incorrect viewpoints (Goleman, 1985). Just as creative individuals are risk-takers with a strong sense of self-efficacy (Hill, Tan, \& Kikuchi, 2008), reflective practitioners confidently approach analysis of their potential misconceptions as an opportunity for growth (Brookfield, 2012).

Process. Creativity begins with problem-finding, akin to Brookfield's (1987, 1988) suggestion that critical reflection is driven by assumption analysis, which unearths deeply held beliefs to reveal problems in existing mindsets and opportunities for change. One of the most well-known descriptions of the creative process is Wallas's (1926) stage theory, which asserts that creative thinking progresses through the following stages: Preparation, during which the individual identifies a problem and gathers relevant resources, Incubation, which involves setting the problem aside, Illumination, which refers to the coveted a-ha moment of creative problem-solving, and Verification, during which the individual tests his or her new ideas. An additional step, Implementation, is often proposed to emphasize the importance of putting a new idea into action. This process mirrors Kolb's (1984) Experiential Learning Cycle, which is commonly cited throughout the literature on reflection. This cycle includes the following stages: Concrete Experience, which refers to a real-world experience, Reflective Observation, during which individuals consciously and subconsciously ponder the differences between expectation and reality, Abstract Conceptualization, which is the a-ha moment that leads to a modified understanding, and Active Experimentation, during which newly formed beliefs are applied to the real world. Just as a final stage, Implementation, is often added to Wallas's stage theory of creativity, Gibbs' (1988) reflective cycle contains a final implementation stage in which individuals create and implement action plans based on new interpretations of their experiences.

Press. Environments that provide extended time and engagement with multiple modalities are conducive to both reflective and creative thinking (McNamara, 1990; Mednick, 1962; Noffke \& Brennan, 1988). Such open-ended and flexible environments motivate individuals to rely less on routine, pre-determined interpretations of experiences, and thus approach familiar problems from new perspectives (McNamara, 1990). Furthermore, collaborative environments that provide positive challenge and support are conducive to creativity, just as collaborate environments that unite individuals with diverse viewpoints encourage critical reflection
(Hennessey \& Amabile, 20I0; Ramsey, 2004). Such collaborative environments are only effective if they safely promote tolerance and encourage individuals to take creative risks, providing the appropriate support and challenge as individuals uncover potentially difficult assumptions or misunderstandings (Runco \& Sumners, 20I5; Hartman, 200I).

Product. Just as creative products are described as original and appropriate (Runco \& Jeager, 20I2), critical reflection results in new understandings that pave the way for transformative learning. Reflection often results in a shocking uncovering of assumptions and restructuring of understandings, giving birth to the element of surprise that often characterizes creative ideas (Boden, 1996).

\section{STATEMENT OF SUBJECTIVITY}

Before further explaining the study, it is important to articulate my personal interest in the investigation of the reflective thinking process. What follows is a summary of my personal interest in the study, which illustrates my commitment to the systematic "monitoring of the self" that helps me remain aware of how my subjectivity may potentially influence the study and its findings (Peshkin, 1988; p. 20).

As a child, my favorite activity was playing school. I assumed the role of my favorite teachers, mimicking their teaching strategies and pretending that all of my students were engaged in the lesson. As a PST, I arrived early to my first field experience placement - I spent hours preparing my lesson, but as I walked nervously into the classroom I realized that my students didn't resemble the attentive pretend classes that I taught as a child. The class was quite diverse; students were white, African American, Hispanic, and Asian. Some were perched in their chairs, watching me curiously. Others sat with their heads on the table, mindlessly doodling or writing notes to friends. I often come back to this moment when I realized that teaching in the "real world" hardly resembles textbook case studies or pretend play. For several years, I tried to fix the "problems" I saw in the classroom, doing everything in my power to make my teaching experiences live up to my expectations. It was only when I began to study educational psychology and reflect on my teaching and learning experiences that I realized I was part of the problem.

Throughout my K-I 2 educational experiences, I was heavily involved in creative problem-solving programs that taught me to look for new and innovative ways to solve problems. My passion to creatively express myself eventually became an area of academic interest as I embarked on my doctoral studies in gifted and creative education. During my second year, I was member of a seminar in which I met with a small group of doctoral students and faculty members to reflect on our work in a local Title One School. As I listened to other doctoral students explain their perceptions of our work, I quickly realized that my view of teaching and learning was narrow at best. The combination of reflective and creative thinking challenged me to unpack my assumptions and misunderstandings; as a group, we constantly explored our experiences from multiple perspectives and collaborated to design innovative strategies to meet the needs of our students. Throughout this seminar, I discovered that I had my own view of successful teaching, which was largely based on my educational experiences as a white, upper-class student in the Southeastern United States. I assumed what inspired me would inspire my 
students, and aimed to emulate my favorite teachers, replicating practices that I had equated with success.

Since it took me several years to recognize that I was operating under a narrow view of teaching, I have always wanted to closely investigate future educators as they encounter "real-world" teaching experiences for the first time. During my first year teaching introductory educational psychology, I was alarmed by how few connections my students made between the course content and their field experiences. This inspired me to investigate the literature on reflection through the lens of creativity, and assume a more systematic approach when observing students who showed advanced reflective practice. Throughout my second year, I noticed that the highly reflective students were different: they approached problems in class in unique manners, they asked me honest (and often somewhat offensive) questions about the realities of teaching, and they were always eager to unpack new experiences. At the close of the year, I decided to empirically investigate what characterized these highly reflective students, and thus, the current study was born.

\section{METHODOLOGY}

Driven by the desire to better understand advanced reflective practice, the research question was as follows: How do PSTs, categorized as advanced levels of reflectors, differ from others in regards to: (a) overall creativity and specific creative competencies; (b) honesty communicated through writing samples; and (c) descriptions of field experiences?

The study used a mixed-methods approach. Judges were trained to score field experience reflection essays using Harland and Wondra's (20I I) Framework of Four Levels of Reflection for Teacher Education, and participants were sorted into four levels based on the level of reflective ability demonstrated. Creative potential was assessed by the Torrance Tests of Creative Thinking-Figural, and quantitative analyses were used to investigate potential differences in creative potential across levels of reflective ability. Thematic analysis techniques were used to determine overall themes from text segments coded at the highest level of reflection and investigate how participants who produced these texts described their field experiences.

\section{Participants}

All participants were undergraduate students enrolled in an introductory educational psychology course with a field component at a large university in the Southeastern United States. Participants received one research credit in exchange for participating in the study.A total of 47 PSTs signed up to participate in the study, five of which did not arrive at the research location, resulting in a final sample of 42 participants. Of these participants, $78 \%$ identified as female and $21 \%$ as male. Eighty-one percent identified as White, $10 \%$ as Asian Pacific, $8 \%$ as Hispanic, and $2 \%$ as African American. The majority of the students (67\%) were between 18 and 20 years old, with the remaining $31 \%$ between the ages of 21 and 23, and $2 \%$ between the ages of 27 and 29 .

As part of the course requirements, all participants were required to complete at least ten hours in an education field placement of their choice. Field placements were coordinated by the students, and thus ranged in both frequency (length of each stay and number of visits) and location (e.g., community outreach centers, one-on-one tutoring, after-school care, etc.).

\section{Materials}

Demographic questionnaire. Participants completed a basic demographic questionnaire, which also contained questions concerning the diversity of the locations of their field experiences. Formatting of the questionnaire precluded the author from collecting data on specific locations of field work, but all participants reported the frequency with which they visited their field location (ranging from frequent short visits to one large visit) and indicated whether this location was very similar, somewhat similar, somewhat different, or very different than their personal $\mathrm{K}-\mathrm{I} 2$ educational experiences.

Field experience reflection paper. Pre-service teachers completed ten hours of field experience in an educational environment of their choice and reflected on this experience in a final paper, which was due for course credit before data collection began. Reflection papers were required to be about three pages in length, and PSTs were instructed to address the following general topics in their writing: (a) describe the learning environment where they volunteered/worked; (b) relate their experience to class content, and (c) reflect on how the experience expanded their view of learning and teaching. Pre-service teachers in all sections of the course received the same directions and grading rubric for this assignment.

Framework of Four Levels of Reflection for Teacher Education. Field experience reflection papers were scored for reflective ability using Harland and Wondra's (20I I) Framework of Four Levels of Reflection for Teacher Education. Based on an extensive review of the literature on reflection (Kember et al., 2008; Wong et al., 1995; Hatton \& Smith 1995; Gulwadi, 2009; Spalding \& Wilson 2002), this tool was developed for the assessment of reflection within the specific context of future educators working in field placements.

As previously described, the Framework sorts reflective writing into four depth of reflection (DoR) levels: Non-Reflection, Understanding, Reflection, and Critical Reflection. Reflective writing samples are scored for instances of each level of reflection, and a Highest-Incidence DoR (HI-DoR) score is assigned based on the highest level of reflection identified at any point in the writing sample. Thus, writing samples are coded at the whole paper, rather than text segment level. This facilitates inter-rater reliability, since coders are unlikely to agree on DoR scores for specific text segments, but typically reach $100 \%$ consensus on the HI-DoR score (see Harland \&Wondra, 20I I; Kember et al., 2008). Table I describes each level of the Framework and provides an example of corresponding text segments from the field experience reflection papers.

Torrance Test of Creative Thinking-Figural form A. The Torrance Tests of Creative Thinking-Figural (TTCT-Figural) is the most widely used and referenced measure of creative potential (Davis, 1997; Kim, 20I I). The test was developed by E. Paul Torrance in the late 1950s, and has since been normed five times, most recently in 2016 (see Torrance, 1962; 1963 for Torrance's first published descriptions of the test). The TTCT-Figural displays adequate reliability and validity (Kim, 2006; Treffinger, 1985), and scores on the TTCT-Figural predict $(r=.33)$ creative achievement better than any other measure of creative or divergent thinking (Kim, 2008). The TTCT-Figural has impressively large norming samples, with longitudinal validations (Davis, 1997), as well as high predictive validity over a wide age range (Cropley, 2000). 


\begin{tabular}{|c|c|c|}
\hline Level & Description & Example \\
\hline Non-Reflection & $\begin{array}{l}\text { Simple descriptions of experience; no } \\
\text { connection to theory }\end{array}$ & $\begin{array}{l}\text { The students that I was working with were in various grades in high school and most of } \\
\text { the time I tutored them in English. (Amy, para. I) }\end{array}$ \\
\hline Understanding & $\begin{array}{l}\text { Description of experiences in light of } \\
\text { course content }\end{array}$ & $\begin{array}{l}\text { At snack time, I broke his graham cracker in half and he got really excited because he had } \\
\text { "two" graham crackers instead of one. This reminded me of the concept of conservation } \\
\text { that we talked about in class. (Rob, para. } 4 \text { ) }\end{array}$ \\
\hline Reflection & $\begin{array}{l}\text { Interpretations of experiences that inform } \\
\text { future practice }\end{array}$ & $\begin{array}{l}\text { I realized how difficult it could be to help someone overcoming a learning handicap that } \\
\text { they place on themselves...In my future classroom, I will make a specific effort to address } \\
\text { these underlying affective needs that impact student learning. (Clarence, para. 2) }\end{array}$ \\
\hline Critical Reflection & $\begin{array}{l}\text { Interpretations characterized by the } \\
\text { transformation of basic assumptions and a } \\
\text { commitment to change }\end{array}$ & $\begin{array}{l}\text { I have a fear that I will stereotype my students before getting to know them, and then I } \\
\text { will be blind to the other talents and abilities they have that I just assumed they would } \\
\text { not. (Adelaide, para.3) }\end{array}$ \\
\hline
\end{tabular}

Although there are two parallel forms ( $A$ and $B$ ) of the TTCT-Figural, this study used just Form $A$ to facilitate data analyses. The TTCT-Figural form A is composed of three activities, each of which is ten minutes in length. In Activity I, participants construct a picture using a single figural stimulus. Activity II requires participants to create a picture or pictures using ten incomplete figures. Finally, Activity III contains three pages of lines that participants use to create a picture or pictures (Torrance, 1966; Kim, 2006).

The TTCT-Figural is scored for five norm-referenced subscales: Fluency (number of ideas), Originality (number of statistically infrequent ideas), Elaboration (number of added ideas), Abstractness of Titles (degree beyond concrete labeling), and Resistance to Premature Closure (degree of psychological openness), as well as a Creative Strengths Subscale composed of thirteen creative personality traits (Torrance \& Ball, 1984; Torrance, 1990). Artistic quality is not required to receive credit for any subscales (Chase, 1985). An overall Creativity Index (Cl) score can be calculated by averaging the standard scores of the five normed-referenced measures and awarding additional points for Creative Strengths, as indicated in the TTCT Norms-Technical Manual (Torrance, 1998).

\section{DATA COLLECTION AND ANALYSIS}

Data collection spanned two weeks at the end of the academic semester. The first portion of the study was completed online at the research location, and data were collected via an online survey software. After reviewing the consent form and agreeing to participate in the study, participants completed a demographic questionnaire and uploaded a confidential copy of their field experience reflection paper. Once all participants in the research group completed the online measures, participants took a short break before transitioning to the TTCT-Figural, which was a paperand-pencil measure. The TTCT-Figural took about forty minutes to complete, including a warm-up exercise and a short break between the second and third activities.

Scoring of the field experience reflection papers for reflective ability. Four judges (including the researcher) collaborated to score the field experience reflection papers using Harland and Wondra's (20I I) Framework of Four Levels of Reflection for Teacher Education. The following scores were reported for each paper: (a) number of paragraphs, (b) Depth of Reflection (DoR) score for each paragraph, (c) contextual theme for each paragraph, and (d) tally of DoR scores for the entire paper (instances of Non-Reflection, Understanding, Reflection, and Critical Reflection). Reflection papers were assigned a Highest Incidence Depth of Reflection Score (HI-DoR) score based on the most advanced level of reflection demonstrated throughout the paper (see Harland \&Wondra, 20I I; Kember et al., 2008), and thus sorted into four levels (Non-Reflection, Understanding, Reflection, and Critical Reflection) for comparison analyses.

The researcher trained the three additional judges before the scoring of field experience reflection papers. Training involved a brief review of the key literature that has investigated reflection in PSTs, as well as an extensive description and discussion of Harland and Wondra's (20II) Framework. Judges independently assigned DoR scores to eighteen practice text segments and discussed the scoring of each segment until 100\% consensus was reached.After the initial training session, each judge had one week to independently score four practice essays. Judges then met for a second training and discussed DoR scores for each paragraph of the practice essays until $100 \%$ consensus was reached. When discussion was complete and all questions were answered, a second set of four practice essays was distributed and judges met again to discuss any discrepancies before scoring the field experience reflection papers.

Forty-two field experience papers were analyzed for the study. Since it was impractical for judges to meet and discuss DoR scores for each paragraph of each paper, all judges scored 12 papers (in order to access inter-rater reliability), one judge scored nine additional papers, and the remaining three judges scored seven additional papers. Two measures of inter-rater reliability, percent majority adjacent agreement and average kappa between judges, were calculated in order to assess the degree that judges consistently coded each paragraph of the 12 papers scored by all judges.

Percent majority adjacent agreement. As suggested in Harland and Wondra's (20II) description of the Framework of Four Levels of Reflection for Teacher Education, judges discussed their scoring of each paragraph of the practice essays until 100\% consensus was reached.When a majority of judges agreed on the DoR score, they were able to quickly convince the final judge to adjust her scoring during these training sessions. Thus, it was decided that a majority agreement ( 3 out of 4 ) between judges was acceptable if the remaining judge assigned an adjacent DoR score. This technique is similar to Stemler's (2004) suggestion to broaden the definition of agreement by including the adjacent scoring categories on the rating scale. Percent majority adjacent agreement was calculated by tallying the number of paragraphs for which the majority of judges assigned the same score (with the remaining judge assigning an adjacent score) and dividing this by the total number of paragraphs in the sample.

Average kappa. Percent agreement should not be used as the sole IRR estimate, since it does not account for agreement due to chance (Cohen, 1960). For this reason, Cohen's kappa for each pair of judges was calculated, and the arithmetic mean of these estimates was determined in order to provide an overall 
agreement for scoring of all paragraphs for the twelve papers (Light, 197I).

Qualitative analysis of text segments coded at the highest levels of reflection. Thematic analysis (see Boyatzis, 1998; Braun \& Clarke, 2006; Roulston, 200I) was used to examine patterns and overarching themes in paragraphs with DoR scores of Reflection and Critical Reflection. Engagement with the literature related to the qualitative data being analyzed has been shown to enhance thematic analysis by sensitizing the researcher and improving the ability to recognize more subtle features of the data (Tuckett, 2005). Thus, the researcher read all of the field experience papers and generated initial codes based on her knowledge of the literature on reflection. These initial codes were then compared to contextual themes assigned by all judges, and a concise list of over-arching themes across all paragraphs with a DoR Reflection or Critical Reflection was created. Field experience papers were then analyzed through the lens of these themes in order to create a vivid and informative overview of text segments indicative of advanced reflective thought (Braun \& Clarke, 2006; Guest, 2012).

Scoring of the TTCT-Figural. All participants in the study completed Form A of the TTCT-Figural, which was scored for all subscales (Fluency, Originality, Elaboration, Resistance to Premature Closure, and Abstractness of Titles) and the Checklist of Creative Strengths, according to protocol in the scoring manual (Torrance, 1990). Overall Creativity Index (Cl) scores were calculated by averaging the standard scores for grade 13 (college and above) for Fluency, Originality, Closure, and Titles, and adding the score on the Checklist of Creative Strengths. A second judge scored eight of the 42 tests, and inter-rater reliability was assessed by calculating the Intraclass Correlation Coefficient (ICC) for Creativity Index scores, as well as scores for each subscale and the Checklist of Creative Strengths.

TTCT-Figural scores across levels of reflection. Comparison analyses were limited due to uneven sample size across Highest Incidence Depth of Reflection Scores. Thus, the four levels of reflection were collapsed into two (Low and High) levels as follows: HI-DoR scores of Non-Reflection or Understanding = Low Reflectors, and HI-DoR scores of Reflection and Critical Reflection $=$ High Reflectors. Means and standard errors of overall and individual index scores on the TTCT-Figural for both the Low and High Reflector groups were calculated and compared using independent-samples t-tests.

\section{FINDINGS}

Reliability of Judges' Depth of Reflection Scores for Each Paragraph of Field Experience Papers. After judges reached $100 \%$ consensus in scoring of practice text segments, each judge independently scored 12 of the 42 field experience papers. There was $88 \%$ majority adjacent agreement between judges for DoR scores. Cohen's kappa was computed for each pair of judges, and all values were statistically significant $(p<.001)$ : $\kappa$ (Judge One and Two $)=.63 ; \kappa$ (Judge One and Three $)=.60 ; \kappa$ (Judge One and Four) $=.52 ; \kappa$ (Judge Two and Three) $=.53 ; \kappa$ (Judge Two and Four $)=.55$; and $\kappa$ (Judge Three and Four) $=.57$. These values were averaged to provide a single index of IRR (Light, I97I), and the resulting kappa indicated moderate agreement, $\kappa=.59$ (Landis \& Koch, 1977).

Highest Incidence Depth of Reflection Scores for field experience papers. Highest Incidence Depth of Reflection scores were assigned based on the highest instance of reflec- tion demonstrated throughout the entire paper. Of the 42 papers analyzed, one (2\%) received a HI-DoR score of Non-Reflection, 14 (33\%) of Understanding, 22 (52\%) of Reflection, and five (I2\%) of Critical Reflection. Table 2 summarizes responses describing the nature of field experiences from participants who earned HI-DoR scores of Reflection or Critical Reflection.

\begin{tabular}{|c|c|c|c|}
\hline & & $\begin{array}{l}\text { Reflection } \\
\text { Freq (\%) }\end{array}$ & $\begin{array}{l}\text { Critical Reflection } \\
\text { Freq (\%) }\end{array}$ \\
\hline \multirow{5}{*}{$\begin{array}{l}\text { Similarity to K-12 } \\
\text { Experience }\end{array}$} & Very Similar & $3(14)$ & $0(0)$ \\
\hline & Somewhat Similar & $4(18)$ & I (20) \\
\hline & Somewhat Different & $3(14)$ & $3(60)$ \\
\hline & Very Different & $9(4 I)$ & $\mathrm{I}(20)$ \\
\hline & NA & $3(14)$ & $0(0)$ \\
\hline \multirow{4}{*}{$\begin{array}{l}\text { Timeline of Field } \\
\text { Experience }\end{array}$} & One session & I (5) & $0(0)$ \\
\hline & 2 sessions & $3(14)$ & $0(0)$ \\
\hline & 3-4 sessions & $3(14)$ & I (20) \\
\hline & $\geq 5$ sessions & $15(68)$ & $4(80)$ \\
\hline
\end{tabular}

TTCT-Figural Scores Across Levels of Reflection. A high degree of reliability was found between the two judges' creativity index scores for the TTCT-Figural; ICC $=.95$ with a 95\% confidence interval from .78-.99 $(F(7,7)=40.21, p \leq .00 \mathrm{I})$. Highest Incidence Depth of Reflection scores were collapsed into two categories (Low and High Reflectors) in order to allow for comparison of means on creativity measures across levels of reflection. Fifteen participants were categorized as Low Reflectors (one participant with a HI-DoR score of Non-Reflection and I 4 with HI-DoR scores of Understanding) and twenty-seven as High Reflectors (22 with HI-DoR scores of reflection and five with HI-DoR scores of Critical Reflection). Table 3 summarizes scores on the TTCT-Figural for participants categorized as Low and High Reflectors.

\begin{tabular}{|c|c|c|}
\hline TTCT-Figural Score & $\begin{array}{l}\text { Low Reflectors } \\
\text { Mean (SD) }\end{array}$ & $\begin{array}{l}\text { High Reflectors } \\
\text { Mean (SD) }\end{array}$ \\
\hline Creativity Index & $132.83(11.35)$ & $138.39(10.44)$ \\
\hline Fluency & $99.87(13.16)$ & $105.67(14.07)$ \\
\hline Originality & $99.13(16.10)$ & $104.15(13.08)$ \\
\hline Elaboration & $155.40(8.10)$ & $157.30(5.12)$ \\
\hline Titles & 119.47 (II.32) & $129.78(15.57)$ \\
\hline Closure & $103.87(15.78)$ & $104.93(26.56)$ \\
\hline Checklist & $17.20(2.73)$ & I7.II (2.36) \\
\hline \multicolumn{3}{|c|}{$\begin{array}{l}\text { Notes. SD = Standard deviation. Creativity Index scores were calculated by } \\
\text { determining the arithmetic mean of the standard scores for each subscale } \\
\text { and adding the points from the Checklist of Creative Strengths. Standard } \\
\text { scores for grade I } 3 \text { (college and above) were used for these calculations. }\end{array}$} \\
\hline
\end{tabular}

An independent samples t-test was conducted to compare scores on the TTCT-Figural in the Low and High Reflector groups. There were no potential outliers. Normality was assessed using the Kolmgorov-Smirnov test, and homogeneity of variances was assessed by Levene's test. Residuals were normally distributed ( $p$ $=.20)$ and there was homogeneity of variances $(p=.88)$.

Although the mean Creativity Index score for High Reflectors was higher than that of the Low Reflectors, the difference was not statistically significant. Mean scores on each subscale of the TTCT-Figural for High Reflectors were higher than those of Low Reflectors, and one of these differences, in the scores for Abstractness of Titles, was statistically significant: $t(40)=-2.25$, $p<.05$. 


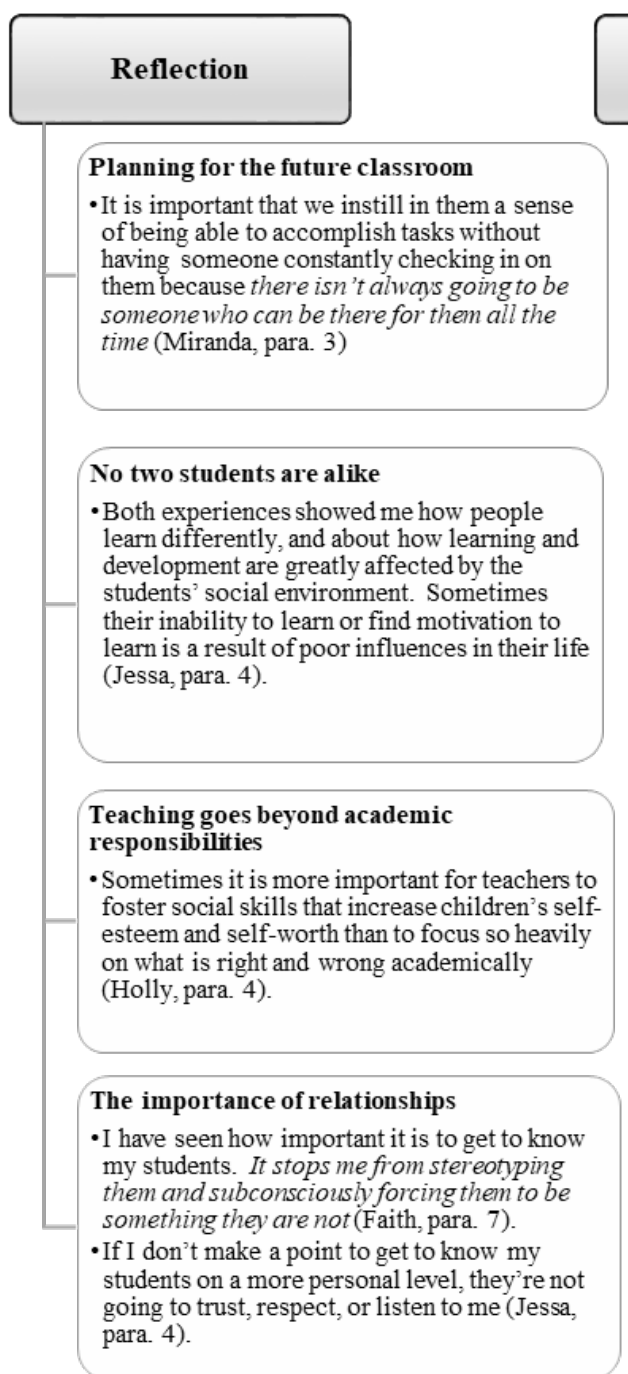

Critical Reflection

Disatisfaction with the status quo

-I believe that the law about inclusion is very helpful in many ways, but I sometimes felt as if these children that had different learning disabilities should be pulled out to better focus on what they are learning, so that switching to different concepts quickly doesn't overwhelm them (Hanna, para. 3)

Shift in perspective about teaching

-I do believe that I saw a different aspect to teaching that I never had before. I kind of always thought that teaching came naturally and all it took was having a goodvision and being good with children (Jada, para. 5)

\section{Realization of an assumption about student} populaitons

- Before tutoring a student with ADHD, I did not believe it was a real disorder. I thought that it was an excuse to give to misbehaving students (Vincent, para. 8)

Figure I. Overarching themes for paragraphs with DoR scores of Reflection or Critical Reflection. Contextual themes appear in bold and excerpts from reflection essays are included under each theme. Quotes that illustrate the blunt honesty found to characterize High Reflectors are emphasized in italics.

Analysis of Paragraphs Coded at the Highest Levels of Reflection. Thematic analysis techniques revealed overarching themes of paragraphs which received DoR scores of Reflection or Critical Reflection, as summarized in Figure I. Quotes that illustrate the blunt honesty found to characterize High Reflectors are emphasized in italics.

\section{DISCUSSION}

Findings indicated a general lack of evidence of Critical Reflection among PSTs, a somewhat alarming incident that has been demonstrated by several past studies that investigated reflection in populations of future teachers (Farr and Riordan, 2015; Harland \& Wondra, 20 I I; Hatton \& Smith, 1995; King, 1997; Sellars, 20 I4;Yang, 2009). However, although only five instances of Critical Reflection were found in the entire sample, it is important not to conclude that PSTs are generally unable to engage in Critical Reflection. Reflection is an ongoing process, and Critical Reflection is characterized by the unearthing of assumptions and a commitment to change, both of which require a high degree of vulnerability and self-efficacy (Kendall, 1996; King, 1997). Categorizing reflective thought can be useful for research purposes, but it is essential to remember that the actual reflective process is continual and oftentimes messy.

Results revealed commonalties among high reflectors in regards to each component of the research question: (a) overall creativity and specific creative competencies; (b) honesty communicated through writing samples; and (c) descriptions of field experiences.

\section{Creative Thinking of High Reflectors}

Results supported the hypothesized relationship between reflective and creative thinking. Although unequal sample sizes across the four levels of Reflection precluded comparison of TTCT-Figural scores, a positive trend between creative potential and reflective ability was evident when the four levels of Reflection were collapsed into two (Low and High) groups. One of these differences in mean scores (for Abstractness of Titles) was statistically significant, $t(40)=-2.25, p<.05$. A larger sample size would allow a more sophisticated analysis of the relationship between the two thought processes.

It is important to note that the comparison of reflection and creativity was most likely impacted by the nature of the assess- 
ments that attempted to quantify the two constructs. The Field Experience Reflection Paper was clearly a verbal measure, while the TTCT-Figural only had a small verbal component (Abstractness of Titles). Thus, it is possible that there are stronger similarities between reflection and creativity that were overshadowed by the contrasting natures of the two assessments. Future research should employ more verbal measures of creative potential, such as Torrance's (1974) Tests of Creative Thinking -Verbal in order to investigate the relationship between reflection and creativity in a manner that is potentially less impacted by mode of expression. It would also be interesting to use other methods to assess reflective thinking, since research has indicated that it is important to encourage PSTs to reflect in multiple modalities (Spalding \&Wilson, 2002).

It is not surprising that the most significant difference in TTCT-Figural scores between Low and High reflectors was in Titles, since this subscale is predominantly verbal in nature. Higher Abstractness of Titles scores could also relate to the ability to consider multiple explanations for an event and attribute non-obvious meanings to experiences. On the TTCT-Figural, if a participant drew a girl smiling and titled it "Girl", he or she would receive a low score for Abstractness of Titles. A title such as "Elation", however, would receive a high score. This ability to abstract is also important to Critical Reflection. For example, PSTs who see students misbehaving may be quick to label them as "trouble makers", but those who consider multiple viewpoints may consider less obvious explanations for the behavior, suggesting that the students express creativity in unique manners, or are motivated to entertain and support their peers. This ability to resist quick fixes and consider multiple explanations for experiences that are beyond the obvious is essential to reflective thought (Boody, 2008).

It is important to clarify that creative potential was solely measured by the TTCT-Figural; while it would be interesting to measure creativity in the reflective writing samples, such an attempt would be convoluted by the fact that each participant was reflecting on unique experiences. The aim of the present study was to investigate whether participants who demonstrated advanced reflective skills shared commonalities in terms of creative potential; in short, did the participants with advanced reflective ability also show advanced creative thinking skills? Results revealed a positive trend between the two thought processes, which is essential to the understanding of the reflective process: since the two thinking skills seem to work tangentially, it can be hypothesized that training for creative thinking can be used to simultaneously support the development of reflective practice (see Implications for more details).

\section{Honesty in Writing Samples from High Reflectors}

As indicated in Figure I, qualitative analyses indicated that the High Reflectors' writing samples were characterized with honest, often blunt confrontations of previous misunderstandings or assumptions. Text segments that received DoR scores of Reflection were characterized by the general realization that teaching is "more than meets the eye", and a more informed and mature understanding of the relational component of the teaching profession:"sometimes it is more important for teachers to foster social skills that increase children's self-esteem and self-worth than to focus so heavily on what is right and wrong academically" (Holly, para. 4). Furthermore, text segments with DoR scores of Critical Reflection progressed beyond the creation of personal teaching philosophies to express dissatisfaction with the status quo and demonstrate fundamental shifts in understanding, as illustrated by Hanna's frustration with special education practices andVincent's shifted perception concerning ADHD.

Ironically, text segments coded at the Critical Reflection level were characteristically blunt, lacking the flowery, cliché language that Harland and Wondra (20I I) claimed to be indicative of lower levels of reflective thought. For example, Jake ended his paper with a well written, yet ultimately cliché and uninformative text segment that received a DoR score of Understanding: "This [self confidence] is what will carry them through life. This is what will help them not just hope for a better future, but step, walk, and even run for a better future (para. 3)". Such a statement starkly contrasts Vincent's blunt confession that he initially did not believe ADHD was a real disorder, but rather "an excuse to give to misbehaving students" (para. 8), which was indicative of Critical Reflection.

The surplus of trite and cliché statements throughout the field experience reflection papers scored as Low Reflectors could be attributed to the fact that students often attempt to demonstrate knowledge and hide ignorance if they know their reflections are reviewed by tutors or other individuals in authority (Boud, 1999; Sumsion \& Fleet, 1996). As previously discussed, Critical Reflection requires a fair amount of risk-taking and vulnerability, particularly when PSTs articulate potential misunderstandings that they have discovered concerning specific populations (Ford, Harris, Tyson, \& Trotman, 2002; Kendall, 1996; King, 1997). It is thus likely that some PSTs found comfort in cliché statements such as "the experience changed me forever", choosing to resist the discomfort and risk that accompanies critically investigating potential misunderstandings and assumptions.

\section{Field Experiences of High Reflectors}

As shown in Table 2, a full eighty percent of the participants who demonstrated Critical Reflection indicated that they worked in environments somewhat or very different than their personal $\mathrm{K}-\mathrm{I} 2$ educational experiences. Furthermore, all of these individuals completed fieldwork in short segments throughout the semester $(80 \%$ visited their placement 5 or more times, and the remaining $20 \%$ visited the placement 3-4 times). A similar trend can be seen in those with DoR scores of Reflection: $55 \%$ described their field experience as "somewhat" or "very different" than their personal K-I 2 educational experiences, and $68 \%$ visited their placement five or more times.

Working in unfamiliar environments is likely to jerk individuals out of their comfort zones, which stimulates assumption analysis when expectations do not match reality (Brookfield, 1987; 1988) and supports Boud and Walker's (1998) assertion that "context is perhaps the single most important influence on reflection and learning" (p. 196). It is quite likely that PSTs working in unfamiliar environments encountered "critical incidents" that lead them to check their assumptions through critical reflection (James \& Brookfield, 2014). Engaging in fieldwork throughout the semester, rather than in one large chunk of time, encourages PSTs to continually challenge their expectations with real-world experiences. Indeed, as PSTs shift from learning about educational theory in teacher preparatory classes and working in educational 
environments, they are truly embodying the gap between theory and practice.

The impact of working in environments that contrast personal educational experiences is particularly important in light of the notion of culturally responsive teaching. As student populations continue to diversify, pre-service teachers are confronted with increasingly multinational and multicultural issues (Colley, Bilics, \& Lerch, 2012). In order to teach in a manner that not only addresses, but also embraces diversity in the classroom, it is essential that teachers have a firm understanding of their personal beliefs (Kendall, 1996). Qualitative analysis of text segments indicative of higher levels of reflection further supported the transformative power of reflective thinking. As one participant suggested, "I have seen how important it is to get to know my students. It stops me from stereotyping them and subconsciously forcing them to be something they are not." (Faith, para. 7).

\section{IMPLICATIONS}

This study has several implications for the field of teacher preparation. Evidence supporting the relationship between reflective and creative thinking informs the creation of instructional strategies to support the development of reflective thinking. Although direct instruction for reflective thinking is rare (Choy \& Oo, 2012; James, 2007; Rodgers, 2002), several instructional techniques have been empirically proven to help individuals fulfill their creative potential (see Runco \& Sumners, 20I5), and it is likely that creative teaching strategies could be simultaneously used to successfully encourage the development of reflective thinking skills.

The Incubation Model of Teaching (IMT), for example, is a practical method to deliver academic content while simultaneously supporting the development of creative problem-solving skills. The model's three stages (Heightening Anticipation, Deepening Expectations, and Keeping It Going) guide students through the creative thinking process, encouraging them to extend learning beyond the classroom and resist the temptation to draw quick conclusions (Torrance, 1979; Torrance \& Safter, 1990). These three stages clearly overlap Rolfe, Freshwater, and Jaspers' (200I) well known 'What? So what? Now what?' model for reflective thinking, and the creative strategies proposed for the IMT could be applied to simultaneously support the development of both creative and reflective thinking skills. Following the research presented in this study, the author re-designed a teacher prep course to encourage reflection through this creative teaching strategy, and results demonstrated a significant improvement in reflective thinking skills when students were compared to a control group that followed the traditional teaching methods (Author, manuscript in progress).

It is important to note that text segments coded at the highest levels of reflection required a general sense of vulnerability and honesty from PSTs. Teacher educators should keep this in mind as they discuss reflection with their students, emphasizing the importance of the reflective process over the final product, and establishing a safe environment for future educators to critically examine challenging experiences. Teacher educators should avoid grading reflective writing, and even provide opportunities for anonymity so that PSTs feel comfortable honestly expressing their concerns. Given the relationship between reflective and creative thinking, careful investigation of creative press (environments that are conducive to creative productivity) should also inform the creation of learning environments that support advanced reflective practice (see, for example, Runco \& Sumners, 20I5).

Finally, results demonstrated the importance of carefully crafting field experiences for future educators. Given that the majority of PSTs who produced reflective writing samples coded at the highest levels of reflection reported that they worked in educational environments that contrasted their personal educational experiences, teacher educators should resist taking a "one-size-fits-all" approach when helping students select field experience placements. Future educators are often required to design their own field experiences in introductory education classes, which was the case for participants in the current study. Some participants chose to work in familiar environments (e.g. assisting their favorite past teachers), but others selected placements that exposed them to new, less comfortable settings (e.g. working with students who spoke a different native language). Although working outside of one's comfort zone takes risk, teacher educators should support future teachers in the careful selection of field experience placements that will challenge them and stimulate meaningful reflection. Furthermore, teacher educators should encourage PSTs to visit field placements frequently and guide them to analyze experiences through perspectives rooted in research-based theories of teaching and learning, rather than personal interpretations.

\section{LIMITATIONS AND FUTURE DIRECTIONS}

There was a lack of participant diversity in terms of indicated gender and ethnicity (78\% identified as female and $81 \%$ identified as white) which must not go unnoticed. This is of particular importance in terms of the qualitative analyses, as many reflections about unfamiliar experiences seemed to be written from a "majority perspective" (e.g., a student who grew up in a private school wrote of his first experience in a Title One School). The design of the demographic questionnaire precluded the collection of specific locations of field experiences; future studies should not only investigate which types of locations were most popular, but also explore why students choose to complete their field requirements in certain locations over others.

An additional limitation of the study was the uneven sample sizes across Highest Incidence Depth of Reflection scores, which limited comparison analyses between HI-DoR scores and scores on the TTCT-Figural. A fair amount of variability was lost when field experience papers were categorized into four levels (e.g. a paper with two instances of reflection received the same HI-DoR score as a paper with just one instance of reflection), and collapsing the four levels into two further contributed to this lack of variance. Despite this issue, the literature is quite clear that reflective writing should be assessed at the whole-paper, rather than the text-segment level (see Harland \& Wondra, 20I I; Kember et al., 2008; Marton et al. 1993). Essays consist of various pieces that fit together to create a whole, and it is difficult to score individual text segments without considering how they fit together holistically (Kember et al., 2008).

Although assessment of reflective essays and journals is common in teacher education programs, this method only addresses final written reflections and does not necessarily capture the ability to reflect in action (Lee, 2005; Schon, 1983). Research has shown that individuals prefer to reflect in multiple modalities, and thus sorting reflective writing samples into Harland and Wondra's (20I I) framework may not capture true 
reflective ability (Spalding \& Wilson, 2002). Further research should investigate how to capture reflective ability in a more holistic manner (potentially by analyzing multiple indicators of reflection) in order to gain a more accurate measure of reflective thinking that could be compared to creative potential. As previously mentioned, additional measures of creative potential, such as the TTCT-Verbal, should also be used.

Future educators may be fueled by life-long dreams to have a classroom of their own, but it is essential that teacher preparation programs equip PSTs to adapt such aspirations to meet the needs of their students and resist temptations to fit real-world experiences into the mold of personal expectations. No two students are the same, and prescribed teaching methods often neglect to meet and capitalize on the diverse strengths and interests of today's student populations. Effective teacher preparation programs must progress beyond empty assertions to cultivate reflective practitioners who approach the classroom through an inquiry stance, and provide future educators with well-crafted instruction and field experiences that prepare them to "take the creative leap beyond" and effectively serve all students (Torrance \& Safter, 1999).

\section{REFERENCES}

Badiali, B. J. \& Hammond, D.J. (2002, March). The power and necessity for suing inquiry in a PDS. Paper presented at the Professional Development Schools National Conference, Orlando, FL.

Badiali, B., Nolan, J., Zembal-Saul, C., \& Manno, J. (20I I). Affirmation and change:Assessing the impact of the professional development school on mentor's classroom practice. In J. Nath,W. Irma, \& J.R. Guadarrama (Eds.), Investigating university-school partnerships (pp. 32I-346). Charlotte, NC: Information Age Publishing.

Barnes, H. ( 1 989). Structuring knowledge for beginning teaching. In M. Reynolds (Ed.), Knowledge base for the beginning teacher (pp. 13-22). New York: Pergamon Press.

Barron, F. (1969). Creative person and creative process. New York: Holt.

Bitterman, A., Goldring, R., \& Gray, L. (20I3). Characteristics of public and private elementary and secondary school principals in the United States: Results from the 201 I-12 Schools and Staffing Survey (NCES 2013-3/3). U.S. Department of Education. Washington, DC: National Center for Education Statistics.

Boden, M.A. (1996). What is creativity? In M.A. Boden (Ed.), Dimensions of creativity. Cambridge, MA:The MIT Press.

Boody, R. M. (2008). Teacher Reflection as Teacher Change, and teacher change as moral response. Education, I28(3), 498506.

Borg, M. (2004). The apprenticeship of observation. English Language Teaching Journal, 58(3), 274-276.

Boud, D. (1999). Situating academic development in professional work: using peer learning. International Journal for Academic Development, 4(I), 3-10.

Boud, D., \& Walker, D. (1998). Promoting reflection in professional courses:The challenge of context. Studies in Higher Education, 23(2), I91-206.

Boyatzis, R. E. ( 1998). Transforming qualitative information: Thematic analysis and code development. Thousand Oaks, CA: Sage.
Braun, V. and Clarke,V. (2006) Using thematic analysis in psychology. Qualitative Research in Psychology, 3 (2), 77-I0I.

Brookfield, S. D. (1987). Developing critical thinkers: Challenging adults to explore alternative ways of thinking and acting. San Francisco: Jossey-Bass.

Brookfield, S. D. (1988). Training educators of adults:The theory and practice of graduate adult education. New York: Routledge.

Brookfield, S. D. (20I2). Teaching for critical thinking. San Francisco, CA: Jossey-Bass.

Buchmann, M. (1987). Teaching knowledge:The lights that teachers live by. Oxford Review of Education 13(2), I5I-64.

Charyton, C., \& Snelbecker, G. E. (2007). Engineers' and musicians' choices of self-descriptive adjectives as potential indicators of creativity by gender and domain. Psychology of Aesthetics, Creativity, and the Arts, I, 91-99.

Chase, C. I. (1985). Review of the Torrance Tests of Creative Thinking. In J.V. Mitchell Jr. (Ed.), The ninth mental measurements yearbook (pp. I63I-1632). Lincoln: University of Nebraska, Buros Institute of Mental Measurements.

Choy, S.C., \& Oo, P.S. (20I2). Reflective thinking and teaching practices:A precursor for incorporating critical thinking into the classroom? International Journal of Instruction, 5(I), 167-182.

Clark, C., \& Peterson, P. (1986). Teachers' thought processes. In M.Wittrock (Ed.), Handbook of research on teaching (pp. 255-296). New York: Macmillan.

Clarke,A., Triggs, V., \& Nielsen,W. (20I4). Cooperating teacher participation in teacher education:A review of the literature. Review of Educational Research, 84(2), I63-202.

Cochran-Smith, M., \& Lytle, S.L. (1999). Relationships of knowledge and practice: teacher learning in communities. Review of Research in Education, 24, 249-305.

Cohen, J. (1960). A coefficient of agreement for nominal scales. Educational Psychology Measures, 20, 37-46.

Colley, B. M., Bilics, A. R., \& Lerch, C. M. (20I2). Reflection:A key component to thinking critically. Canadian Journal for the Scholarship of Teaching and Learning, 3(I), 2I 3-224.

Cropley, A. J. (2000). Defining and measuring creativity:Are creativity tests worth using? Roeper Review, 23(2), 72-29.

Csikszentmihalyi, M. (1996). Creativity: Flow and the psychology of discovery and invention. New York: Harper Collins.

Darling-Hammond, L. (2000). Reforming teacher preparation and licensing: Debating the evidence. Teachers College Record, 102(I), 28-56.

Darling-Hammond, L. (2006). Why teacher education is important-and difficult. In L. Darling-Hammond (Ed.), Powerful teacher education (19-42). San Francisco: Jossey-Bass.

Davis, G.A. (1997). Identifying creative students and measuring creativity. In N. Colangelo \& G. A. Davis (Eds.), Handbook of gifted education (Pp. 269-28I). Needham Heights, MA: Viacom.

Dewey, J. (1933) How we think:A restatement of the relation of reflective thinking to the educative process. Boston: DC Heath and Company.

Farr, F., \& Riordan, E. (20I5). Tracing the reflective practices of student teachers in online modes. ReCALL: Journal of Eurocall, 27(I), I04-I23.

Ford, D.Y., Harris III, J. J., Tyson, C.A., \& Trotman, M. F. (2002). Beyond deficit thinking. Roeper Review, 24(2), 52. 
Furlong, C. (20|3). The teacher I wish to be: Exploring the influence of life histories on student teacher idealized identities. European Journal of Teacher Education, 36(I), 68-83.

Gareis, C., \& Grant, L. (20I4). The efficacy of training cooperating teachers. Teaching and Teacher Education, 39, 77-88.

Garmon, M.A. (2005). Six key factors for changing preservice teachers' attitudes/beliefs about diversity. Educational Studies: Journal of the American Educational Studies Association, 38(3), 275-286.

Gay, G. (2000). Culturally responsive teaching:Theory, research and practice. New York, Teachers College Press.

Gibbs, G. (1988). Learning by Doing:A guide to teaching and learning methods. Oxford Brookes University, Oxford: Further Education Unit.

Goleman, D. (1985). Vital lies, simple truths:The psychology of self-deception. New York: Simon \& Schuster.

Grossman, R. (2008). Structures for facilitat- ing student reflection. College Teaching, 57, I5-22.

Guest, Greg (20I2). Applied thematic analysis. Thousand Oaks, California: Sage.

Gulwadi, B. B. (2009). Using reflective journals in a sustainable design studio. International Journal of Sustainability in Higher Education, IO(I), 43-54.

Hao, N., Ku,Y., Liu, M., Hu,Y., Bodner, M., Grabner, RH., \& Fink, A. (20I6). Reflection enhances creativity: Beneficial effects of idea evaluation on idea generation. Brain Cognition, 103, 30-37

Harland, D. J., \& Wondra, J. S. (20I I). Teacher candidates' reflections on clinical experiences: A comparison of blog and final paper assignments. Journal of Digital Learning in Teacher Education, 27(4), I28-133.

Hartman, H. J. (200I). Developing students' metacognitive knowledge and skills. In H.J. Hartman (Ed.), Metacognition in Learning and Instruction:Theory, Research and Practice (pp. 33-63). Boston: Kluwer.

Hatton, N., \& Smith, D. (1995). Reflection in teacher education: Towards definition and implementation. Teaching and Teacher Education, I I ( I), 33-49.

Hennessey, B.A., \& Amabile, T.M. (2010). Creativity. Annual Review of Psychology, 6 I (I), 569-598.

Hill, A., Tan, A., \& Kikuchi, A. (2008). International high school students' perceived creativity self-efficacy. Korean Journal of Thinking and Problem Solving, I 8(I), I05-I I5.

Irwin, B. and Boulton, H. (20I0) Analysing the development of professional identity in blogging discourse. In: Rust, C. (ed.), Improving student learning: For the twenty-first century learner. Proceedings of the I 7th Improving Student Learning Symposium. Oxford: Oxford Centre for Staff and Learning Development, 22-32.

James, A. (2007). Reflection revisited: Perceptions of reflective practice in fashion learning and teaching. Art, Design, and Communication in Higher Education, 5(3), I79-196.

James, A. \& Brookfield, S. D. (20|4). Engaging imagination: Helping students become creative and reflective thinkers. San Francisco, CA: Jossey-Bass.

Jay, J. K. and Johnson, K. L. (2002). Capturing complexity:A typology of reflective practice for teacher education. Teaching and Teacher Education, 18,73-85.

John, O. P., Naumann, L. P., \& Soto, C. J. (2008). Paradigm shift to the integrative Big Five trait taxonomy. In A. P. John, R.W.
Robins, \& L.A. Pervin (Eds.), Personality handbook:Theory and research (pp. I I4- I58). New York: Guilford.

Kember, D., McKay, J., Sinclair, K., \& Yuet Wong, F. K. (2008).A four-category scheme for coding and assessing the level of reflection in written work. Assessment and Evaluation in Higher Education, 33(4), 369-379.

Kendall, F. E. (1996). Diversity in the classroom: New approaches to the education of young children. New York, NY:Teachers College Press.

Killeavy, M. \& Moloney, A. (20 I0). Reflection in a social space: Can blogging support reflective practice for beginning teachers?. Teaching and Teacher Education 26, I070- 1076.

Kim, K. H. (2006). Can we trust creativity tests? A review of the Torrance Tests of Creative Thinking (TTCT). Creativity Research Journal, 18, 3-14.

Kim, K. H. (2008). Meta-analyses of the relationship of creative achievement to both IQ and divergent thinking test scores. Journal of Creative Behavior, 42, 106-130.

Kim, K. H. (20I I). The creativity crisis:The decrease in creative thinking scores on the Torrance Tests of Creative Thinking. Creativity Research Journal, 23(4), 285-295.

King, J. (1997). “Thank you for opening our minds": On praxis, transmutation, and black studies in teacher development. In J. King, E. Hollins \&W. Hayman (Eds.), Preparing teachers for cultural diversity. New York:Teachers College Press.

Kolb, D. (1984). Experiential learning: Experience as the source of learning and development. Upper Saddle River, NJ: Prentice Hall.

Landis, J. R., \& Koch, G. G. (1977). The measurement of observer agreement for categorical data. Biometrics, 33, I59-I 74.

Lee, H.-J. (2005). Reflection and teaching:A taxonomy. Teaching and Teacher Education, 21 , 699-7I5.

Light, R. J. (197I). Measures of response agreement for qualitative data: Some generalizations and alternatives. Psychological Bulletin. 76(5), 365-377.

Lortie, D. (1975). Schoolteacher:A sociological study. Chicago: University of Chicago Press.

Lu, L. (20।4). Cultivating Reflective Practiioners in Technology Prepartion: Constructing TPACK through Reflection. Education Sciences, 4(I), I3-35.

Lucas, P. (199I). Reflection, new practices and the need for flexibility in supervising student-teachers. Journal of Further and Higher Education, I5(2), 84-93.

Markos, A. M. (20I2). Mandated to learn, guided to reflect: Pre-Service teachers' evolving understanding of English Language Learners. Issues in Teacher Education, 2 I (I), 39-57.

Marton, F., G. Dall'Alba, \& E. Beaty (1993). Conceptions of learning. International Journal of Educational Research, 19(3), 277-300.

Maxwell, L.A. (20I4). U.S. schools become 'majority minority'. Education Week, 34 (I), I-I6.

McNamara, D. (1990). Research on teachers' thinking: Its contribution to educating student teachers to think critically. Journal of Education for Teaching, I6(2) 147-160.

Mednick, S.A. (1962). The associative basis of the creative process. Psychological Review, 69, 220-232.

Mezirow, J. (1981).A critical theory of adult learning and education. Adult Education Quarterly, 32(3), 3-24.

Mezirow, J. (199I). Transformative dimensions of adult learning. San Francisco: Jossey-Bass. 
Mezirow, J. (1992). Transformation theory: critique and confusion. Adult education quarterly, 42,(4), 185- 198.

National Commission on Teaching and America's Future. (1996). What matters most:Teaching for America's future. New York: Author.

National Council for Accreditation of Teacher Education. (2007). Professional standards for the accreditation of teacher preparation institutions. Retrieved from http://www.ncate.org/ Standards/ProgramStandardsandReportForms/tabid/676/ Default.aspx.

Nicol, C. (2006). Designing a pedagogy of inquiry in teacher education: Moving from resistance to listening. Studying Teacher Education, 2(I), 25-4I.

Nielsen, M. F. (20I4). Sizing up 'the box' in order to fit in. Codesign, $10(2)$, II $2-134$.

Noffke, S., \& Brennan, M. (1988, April). The dimensions of reflection:A conceptual and contextual analysis. Paper presented at the annual meeting of the American Educational Research Association, New Orleans.

Ostorga,A. N. (2006). Developing teachers who are reflective practitioners: A complex process. Issues in Teacher Education, 15(2), 5-20.

Peshkin, A. (1988). In search of subjectivity. One's own. Educational researcher, $17(7), 17-21$.

Piirto, J. (2005). The creative process in poets. In J. C. Kaufman \& J. Baer (Eds.), Creativity across domains. London: Psychology Press.

Ramsey, P. G. (2004). Teaching and learning in a diverse world. New York, NY:Teachers College Press.

Rhodes, M. (196I). An analysis of creativity. Phi Delta Kappan, 42, 305-3II.

Robinson, K. R. (20I I). Out of our minds: Learning to be creative. Chichester, West Sussex: Capstone Publishing Ltd.

Rodgers, C. (2002). Defining reflection:Another look at John Dewey and reflective teaching. Teachers College Record, 104(4), 842-866.

Rosaen, C. L. (2003). Preparing teachers for diverse classrooms: Creating public and private spaces to explore culture through poetry writing. Teachers College Record, 105, |437-| 485.

Roulston, K. (200I). Data analysis and 'theorizing as ideology'. Qualitative Research I, 279-302.

Runco, M.A., \& Jaeger, G., J. (20I2). The standard definition of creativity. Creativity Research Journal, 24(I), 92-96.

Runco, M.A., \& Sumners, S. (20I5). Creativity training. In J. Wright (Ed.), International Encyclopedia of Social and Behavioral Sciences (2nd ed.). Oxford, England: Elsevier.

Schon, D.A. (1983). The reflective practitioner: How professionals think in action. New York: Basic Books.

Sellars, M. (20I4). Reflective practice for teachers. Los Angeles: SAGE.

Spalding, E. \&Wilson, A. (2002). Demystifying reflection:A study of pedagogical strategies that encourage reflective writing. Teachers College Record, 104 (7), I393-I 42 I.

Stemler, S. E. (2004). A comparison of consensus, consistency, and measurement approaches to estimating interrater reliability. Practical Assessment, Research, and Evaluation, 9(4), I-II.
Sumsion, J. \& Fleet, J. (1996). Reflection: Can we assess it? Should we assess it? Assessment and Evaluation, Higher Education, 21 , I $21-30$.

Torrance, E. P. \& Safter, H.T. ( 1999). Making the creative leap beyond. Buffalo, NY: Creativity Foundation Press.

Torrance, E. P. ( 1 962). Guiding creative talent. Englewood Cliffs, NJ: Prentice-Hall.

Torrance, E. P. (1963). Education and the creative potential. Minneapolis: University of Minnesota Press.

Torrance, E. P. (1966). The Torrance Tests of Creative Thinking-norms: Technical manual research edition-verbal tests, forms $A$ and $B$-figural tests, forms $A$ and B. Princeton, NJ: Personnel Press.

Torrance, E. P. (1990). The Torrance Tests of Creative Thinking directions manual, figural forms $A$ and B. Bensenville, IL: Scholastic Testing Service, Inc.

Torrance, E. P. (1998). The Torrance tests of creative thinking norms - technical manual figural (streamlined) forms A \& B. Bensenville, IL: Scholastic Testing Service, Inc.

Torrance, E.P. (1 974). Torrance Test of Creative Thinking: Norms-Technical Manual. Bensenville, IL: Scholastic Testing Service.

Torrance, E.P. (1979) An instructional model for enhancing incubation. Journal of Creative Behavior, I3(I), 23-25.

Torrance, E.P., \& Safter, H.T. (1990). The incubation model of teaching: Getting beyond the aha. Buffalo, NY: Bearly Limited.

Torrance, E. P., \& Ball, O. E. ( I 984). The Torrance Tests of Creative Thinking Streamlined (revised) manual, Figural A and B. Bensenville, IL: Scholastic Testing Service, Inc.

Treffinger, D. J. ( 1 985). Review of the Torrance Tests of Creative Thinking. In J.V. Mitchell, Jr. (Ed.), The ninth mental measurements yearbook (pp. 1632-1634). Lincoln, NE: Buros Institute of Mental Measurements, University of Nebraska.

Tuckett, A. G., (2005). Applying thematic analysis theory to practice:A researcher's experience. Contemporary Nurse, I9(I-2), 75-87.

U.S. Department of Education. (2016). The state of racial diversity in the educator workforce. Washington, D.C: U.S. Department of Education, Office of Planning, Evaluation and Policy and Program Studies Service.

Valentíin, S. (2006). Addressing diversity in teacher education programs. Education, 127(2), 196-202.

Valli, L. (1990). Moral approaches to reflective practice. In R. Clift, W. R. Houston, and M. Pugach (Eds.). Encouraging Reflective Practice in Education (pp. 39-56). New York:Teacher College Press.

Van Manen, M. (1977). Linking ways of knowing with ways of being practical. Curriculum Inquiry, 6, 205-228.

Wallas, G. (1926). The art of thought. New York: Harcourt Brace and World.

Wong, F. K.Y., Kember, D., Chung, L.Y. F., \& Yan, L. (1995). Assessing the level of student reflection from reflective journals. Journal of Advanced Nursing, 22, 48-57.

Yang, S. H. (2009) Using blogs to enhance critical reflection and community of practice. Educational Technology \& Society, I2(2): I I-2I.York: Basic Books. 